\title{
IZABELA GOLONKA
}

Uniwersytet Mari Curie-SkŁodowskiej w Lublinie (Polska)

IZABELAGOLONKA@WP.PL

HTTPS: / / ORCID.ORG/ 0000-0002-3115-9079

\section{Mediatyzacja edukacji na poziomie akademickim. Szanse i zagrożenia z perspektywy studentów i pracowników naukowych - wyniki badań własnych}

\author{
Mediatization of Education at the Academic Level. Opportunities \\ and Threats from the Perspective of Students and Academics - \\ Results of Research
}

\begin{abstract}
Abstrakt. Celem artykułu jest zbadanie szans i zagrożeń wynikających z procesu mediatyzacji edukacji na poziomie akademickim. Po teoretycznym przeglądzie koncepcji mediatyzacji oraz zaprezentowaniu transformacji zachodzących w edukacji pod wpływem nowych mediów i ich logiki opisano postrzeganie samego procesu mediatyzacji edukacji przez studentów i pracowników naukowych Wydziału Politologii i Dziennikarstwa Uniwersytetu Marii Curie-Skłodowskiej w Lublinie. Badania o charakterze eksploracyjnym, z zastosowaniem wywiadów indywidualnych w formie online, pozwoliły na poznanie i przeanalizowanie zmian zachodzących w edukacji oraz sposobów ich postrzegania przez studentów i naukowców. Przemiany w systemie edukacji napędzane przez media są bowiem coraz szybsze i bardziej radykalne. Wyniki badań mogą stanowić podstawę do dyskusji na temat przyszłości szkolnictwa wyższego w obliczu mediatyzacji.
\end{abstract}

Słowa kluczowe: mediatyzacja edukacji; szkolnictwo wyższe; nowe media; system edukacji; edukacja na poziomie akademickim

Abstract. The aim of the article is to examine the opportunities and threats arising from the process
of mediatization of education at the academic level. After a theoretical introduction to the conceptu-
alization of mediatization and presentation of the transformations taking place in education system
under the influence of new media and their logic, the perception of the process of mediatization of
education by students and academic staff of the Faculty of Political Science and Journalism at Maria
Curie-Skłodowska University in Lublin was examined. Exploratory research, with the use of individual
online interviews, made it possible to learn and analyze the changes taking place in education and the
ways of their perception by students and scientists. The changes in the education system driven by the 
media are becoming faster and more radical. The research results can be used as a basis for a discussion on the future of higher education facing a mediatization.

Keywords: mediatization of education; higher education; new media; education system; education at the academic level

\section{Wprowadzenie}

Badania dotyczące mediatyzacji narodziły się w północnej Europie (Niemcy, Skandynawia), a pierwszym badaczem, który wprowadził termin „mediatyzacja” do dyskursu naukowego w 1933 r., był Niemiec - E. Manheim. Rozwój badań niemieckich naukowców był stopniowy; pod koniec XX w. stał się jednym z głównych nurtów badań z pogranicza mediów i komunikacji. To właśnie wtedy rozwinęła się dyskusja na temat nazewnictwa zachodzących w społeczeństwie zmian wywołanych przez media masowe - jedni nazywali je mediacją (Medialisierung), inni zaś mediatyzacją (Mediatisierung) (Lundby, 2014). Mediacja była rozumiana jako regularna komunikacja zapośredniczona przez media, które nieustannie komentują, reprodukują i zastępują się nawzajem, co jest zjawiskiem nieodłącznym dla całej komunikacji pośredniej. Z kolei mediatyzacja obejmuje długoterminowe zmiany kulturowe i społeczne w następstwie rozwoju i wszechobecności ciągłej komunikacji pośredniej. W studiach dotyczących mediatyzacji rozważa się więc długoterminowe przekształcenia strukturalne w zakresie roli mediów we współczesnej kulturze i społeczeństwie.

Mediatyzacja dotyczy szerszego spektrum transformacji, równoległych z takimi zjawiskami jak globalizacja i indywidualizacja. W ramach regularnych procesów pośredniej komunikacji zachodzą zmiany w samych treściach produkcji medialnej, które mają wpływ na ich odbiorców oraz sposób postrzegania przez nich rzeczywistości (Lundby, 2014). Badania dotyczące mediatyzacji obejmują wiele kierunków i zagadnień. Obecnie, w okresie pandemii COVID-19, mamy do czynienia z nasileniem się procesów mediatyzacji. Dotyczą one wielu dziedzin życia zawodowego i codziennego współczesnych ludzi.

Jednym z obszarów, który w dużym stopniu zmienił się w ciągu ostatniego roku, jest edukacja, w tym edukacja na poziomie akademickim. Mediatyzacja edukacji jest aktualnie nowym, ale obiecującym polem badawczym. Nieliczne opracowania z tego obszaru tylko w niewielkim zakresie zostały zaktualizowane o doświadczenia $\mathrm{z}$ okresu pandemii.

Celem badań opisanych w niniejszym opracowaniu było określenie szans i zagrożeń dla edukacji na poziomie akademickim, wynikających z funkcjonowania nowych technologii medialnych. Przedmiotem zainteresowania stały się w szczególności postawy studentów i wykładowców wobec zastosowania tych technologii na uczelniach. Obiektem badania uczyniono również perspektywy zmian w edukacji wyższej związane z postępującą mediatyzacją oraz aktualnie zachodzące zmiany w zakresie 
wykorzystania technologii medialnych w związku z zajęciami prowadzonymi zdalnie z powodu epidemii COVID-19. Zagadnienia te zostały przedstawione z perspektywy zarówno studentów, jak i wykładowców.

\section{Pojęcie mediatyzacji}

Mediatyzacja i terminy jej pokrewne, tj. „medializacja” (medialization), „mediacja” (mediation), „ekologia mediów” (media ecology), „medialność” (mediality), „epistemologia mediów” (media epistemology), „zwrot medialny” (mediatic turn), mają na celu określenie relacji pomiędzy współczesnymi mediami, z uwzględnieniem kluczowych zmian społeczno-kulturowych i ich rolą w społeczeństwie. Badania dotyczące mediatyzacji koncentrują się więc przede wszystkim na strukturalnej roli systemu medialnego w (re)organizacji i tworzeniu relacji społecznych. Przewodnim pytaniem podejścia mediatyzacji nie jest więc ani „co ludzie robią z mediami”, ani też „co media robią ludziom”, lecz „co media robią społeczeństwu” (Adolf, 2013).

Interdyscyplinarne badania mediatyzacji łączą w sobie teorie: mediów, komunikacji społecznej, kultury, psychologii i socjologii. W ramach tych badań utworzyły się dwa główne nurty: instytucjonalny i konstruktywistyczny. Pierwszy z nich, uprawiany głównie przez S. Hjarvarda, J. Strömbäcka i R. Schrotta, skupia się na logice mediów i tym, jak media stają się centralną siłą oddziałującą na kulturę i społeczeństwo, jak inne dziedziny życia ludzkiego podporządkowują się logice mediów oraz w jaki sposób reorganizują swoje działanie, aby dostosować się do mediów.

Podejście konstruktywistyczne kładzie szczególny nacisk na codzienne praktyki komunikacyjne za pomocą mediów tradycyjnych i digitalowych oraz na zmiany kulturowe i społeczne, które z nich wynikają. Konstruktywizm, czyli konstrukcja nowej rzeczywistości społecznej przez media, w połączeniu z instytucjonalistyczną wizją rozwoju mediów i wpływem ich logiki na inne sfery życia składa się na krytyczną analizę społeczno-konstruktywistyczną mediatyzacji autorstwa N. Couldry’ego i A. Heppa.

Połączenie wiedzy teoretycznej z praktycznymi wnioskami wynikającymi z badań jakościowych i ilościowych ma na celu skuteczne wyjaśnienie samego pojęcia mediatyzacji oraz opisanie, w jaki sposób działa zmediatyzowany świat (Nowak-Teter, 2019). W czasach przyspieszonej mediatyzacji (deep mediatization) popularność wśród badaczy zyskała bowiem, łącząca oba podejścia, teoria figuracji komunikacyjnych A. Heppa, stanowiąca perspektywę transmedialną, która zmienia sposób patrzenia na sferę społeczną (social life) i sferę medialną (media life) jako zintegrowaną (Hepp \& Hasebrink, 2018).

Ogólną definicję mediatyzacji w perspektywie kulturowej i społecznej, która swoim zakresem obejmuje również mediatyzację edukacji, opracowali A. Hepp i F. Krotz, którzy określili ją jako związek między zmianami w mediach a komunikacją społeczną z jednej strony, a zmianami w kulturze i społeczeństwie z drugiej. Mediatyza- 
cja określa więc przekształcenie wielu różnych procesów społecznych i kulturowych $\mathrm{w}$ formy i formaty nadające się do ponownego przedstawienia $\mathrm{w}$ mediach oraz tworzenie wspólnych wzorów w różnych obszarach społecznych opierających się na działaniu mediów (Couldry, 2008). Według A. Heppa (2020) mediatyzacja to wzajemna zależność zmian zachodzących w komunikacji i technologii medialnej oraz w kulturze i społeczeństwie.

Poprzez mediatyzację społeczeństwa określany jest proces, w którym społeczeństwo w coraz większym stopniu jest uzależniane od mediów i ich logiki, a także coraz częściej jest im poddawane. Proces ten cechuje się pewną dwoistością, która polega na tym, że media zintegrowały się z działaniami innych instytucji społecznych i same zyskały ich status. $\mathrm{W}$ wyniku tego interakcje społeczne - w ramach odpowiednich instytucji, między instytucjami oraz w społeczeństwie - zachodzą przeważnie za pośrednictwem mediów (Hjarvard, 2008). Media są tu traktowane zarówno jako technologiczne i kulturowe formy determinujące zmiany społeczno-kulturowe (technological determinism), jak i produkty uboczne tych zmian społecznych (symptomatic technology theory) (Hepp, 2012).

Mediatyzacja edukacji, podobnie jak każdy inny rodzaj mediatyzacji (na poziomie makro, mezo i mikro), nie jest pojęciem normatywnym (Hjarvard, 2008), dlatego dyskusja nad tym, czy jest zjawiskiem pozytywnym czy też negatywnym, jest zbędna. Można jednak określić pewne skutki mediów dla edukacji, które - jak zauważa S. Livingstone - są dwojakie. Z jednej strony media cyfrowe bardzo rozszerzyły infrastrukturę edukacyjną, uatrakcyjniły jej formę (m.in. multimedia, edutainment, gamification, wirtualna i rozszerzona rzeczywistość; zob. Frania, 2017) i przyczyniły się do szerokiej rewolucji zachodzącej w nowym społeczeństwie cyfrowym (m.in. rozwój kompetencji medialnych u zmediatyzowanych członków współczesnego społeczeństwa). Natomiast $z$ drugiej strony, co pokazują badania i ankiety przeprowadzone wśród młodych ludzi, pozytywnie sposoby użycia mediów w procesie edukacji ocenia mniejszość młodzieży, większość zaś nastawiona jest raczej na oglądanie niż tworzenie, pobieranie treści zamiast ich publikowanie, śledzenie trendów, a nie ich wyznaczanie (Livingstone, 2014). Problem stanowi również uzależniająca forma nowych mediów, które - używane w sposób nieodpowiedni - mogą prowadzić do zaburzeń funkcjonowania jednostki (tj. FoMO; zob. Dogan, 2019), tzw. umysłowej nieobecności (Spitzer, 2016), nomofobii, bańki informacyjnej (filter bubbles) itd. Bierność i brak chęci do produktywności i aktywności, ograniczone aspiracje uczniów i studentów oraz nieprawidłowe użycie mediów $\mathrm{w}$ trakcie procesu przyswajania wiedzy to problemy, dla których nie znaleziono jeszcze rozwiązania. 


\section{Mediatyzacja edukacji}

Pojęcie mediatyzacji obecnie silnie wiąże się z edukacją medialną. Jednym z efektów mediatyzacji rzeczywistości społecznej jest powstanie nowego pola badawczego - edukacji medialnej. Punktem odniesienia dla tego nowego pola jest pedagogika mediów, zwana też dydaktyką medialną. Obejmuje ona wszelkie wychowawcze aspekty mediów, tj. edukację przez media, rolę mediów w edukacji i edukację medialną (Drzewiecki, 2010).

Pierwszy w badaniach mediów pojawił się aspekt edukacji przez media. Zwracał on uwagę na pełnione przez media funkcje edukacyjną i wychowawczą, które przez badaczy określane są jako preedukacja, ponieważ nie są głównymi zadaniami mediów. Aspekt wykorzystania mediów w edukacji i nauczaniu odzwierciedla przydatność mediów jako środków dydaktycznych. Wraz z ich rozwojem i upowszechnianiem dostępu badacze zaczęli dostrzegać potencjał mediów jako narzędzi, które można wykorzystać w edukacji jako platformę przekazu treści, miejsce wymiany myśli czy usprawnienie i wzbogacenie samego procesu edukacyjnego o nowe bodźce audiowizualne. Edukacja medialna to inaczej wychowanie człowieka do mediów. W ujęciu semiotycznym jest ona nauką o języku mediów, czyli rozszerzeniem tradycyjnej alfabetyzacji o język mediów (Drzewiecki, 2010). Jej istotą jest tworzenie tzw. media literacy, czyli umiejętności, kompetencji medialnych.

Rolą edukacji medialnej jest - oprócz rozwoju twardych kompetencji cyfrowych, związanych z posługiwaniem się i obsługą technologii - wyposażenie zmediatyzowanej jednostki w miękkie kompetencje cyfrowe. Należy zaliczyć do nich przede wszystkim: świadomość swoich zachowań społecznych i działań w sieci, rozsądne korzystanie z prawa do prywatności oraz wzbudzanie świadomości niebezpieczeństw i zagrożeń czyhających na użytkowników w nowych mediach (Czopek, 2016). Edukacja medialna ma w tej perspektywie ogromne znaczenie zarówno dla osób młodych, dla których media i wirtualność stanowią znaczącą część życia, relacji i tożsamości, jak i dla osób starszych, badających i poznających przestrzenie mediów cyfrowych. Obie grupy są w wysokim stopniu narażone na wyłudzanie danych osobowych, manipulację czy nieświadomą rezygnację z ochrony własnych praw.

Edukacja w zakresie umiejętności korzystania z nowych mediów jest niezwykle ważna w dobie mediatyzacji. Dzięki nowej technologii współczesne media, opierające się na algorytmach, mają siłę profilowania użytkowników, przewidywania ich działań, a tym samym wywierania na nich wpływu do różnych celów (politycznych, handlowych, dezinformacyjnych) w łatwy, tani i przerażająco skuteczny sposób (Flak, Kropisz \& Flak, 2019). Zrozumienie praktyki działania i logiki mediów zapewnia ludziom lepsze narzędzia do krytycznego myślenia i zrozumienia motywów, celów i zastosowań mediów. Jest to ważne także ze społecznego punktu widzenia, ponieważ dzięki tej wiedzy ludzie mogą zauważyć i zrozumieć zachodzące w ich otoczeniu 
zmiany, rodzące się nastroje społeczne, sposoby realizacji kampanii wyborczych i wszelkich innych działań publicznych, które wywierają na nich bezpośredni wpływ (Valtonen, Tedre, Mäkitalo \& Vartiainen, 2019).

\section{Materiał empiryczny i metody badawcze}

W celu zbadania zjawisk mediatyzacji edukacji, które zachodzą w ramach działania i funkcjonowania uczelni wyższej, a także zagrożeń i szans wywołanych obecnością nowych mediów oraz wpływu ich logiki na kształt edukacji wyższej przeprowadziłam badania jakościowe w formie wywiadów indywidualnych, częściowo ustrukturalizowanych, wśród studentów i pracowników naukowych Wydziału Politologii i Dziennikarstwa Uniwersytetu Marii Curie-Skłodowskiej (UMCS) w Lublinie, dobranych za pomocą próby celowej. Ze względu na sytuację pandemiczną badania zostały przeprowadzone przy użyciu poczty elektronicznej i mediów społecznościowych, za pomocą których rozsyłane były kwestionariusze zawierające 12 pytań otwartych przeznaczonych dla obu grup respondentów.

Badania zostały podzielone na dwie części. Pierwsza część dotyczyła postrzegania mediatyzacji edukacji przez studentów, a druga - przez pracowników naukowych, których zainteresowania badawcze są tożsame lub bliskie nauce o mediach. Badania przeprowadzono w dniach 14-30 kwietnia 2020 r. Decyzja o ograniczeniu doboru grupy respondentów jedynie do studentów i pracowników naukowych Wydziału Politologii i Dziennikarstwa UMCS jest uzasadniona tym, że są to osoby, których działalność edukacyjna obejmuje naukę o mediach w mniejszym lub większym stopniu. Są to osoby świadome wpływu mediów na życie społeczne i kulturowe, zorientowane $\mathrm{w}$ ich logice i działaniu, a ich obserwacje i postrzeganie procesu mediatyzacji edukacji wyższej stanowią cenne źródło informacji. Wywiady z respondentami pozwoliły na przybliżenie perspektyw postrzegania przemian wywołanych procesem mediatyzacji osób studiujących i świadomych specyfiki tych zmian.

Dobór respondentów w pierwszej części projektu badawczego oparto na strukturze demograficznej i funkcjonalnej Wydziału Politologii i Dziennikarstwa UMCS. Aby zapewnić odpowiedni stopień zróżnicowania respondentów, a jednocześnie reprezentację dla poszczególnych grup ze względu na czynniki demograficzne i związane ze strukturą Wydziału, dobór próby celowej oparto na następujących parametrach: płeć, miejsce zamieszkania, rok, kierunek studiów. Na tej podstawie zgromadzono łącznie 20 kwestionariuszy od 20 studentów Wydziału Politologii i Dziennikarstwa UMCS studiujących w semestrze letnim 2019/2020. Grupie badanych studentów zadano 12 pytań otwartych, których celem było uzyskanie informacji na temat postrzegania i sposobu rozumienia procesu mediatyzacji edukacji przez studentów Wydziału, odnoszących się do pięciu pytań badawczych (tabela 1). 
Tabela 1. Badanie studentów Wydziału Politologii i Dziennikarstwa UMCS

\begin{tabular}{|c|c|}
\hline Pytania badawcze & Kwestionariusz dla studentów Wydziału \\
\hline $\begin{array}{l}\text { 1. Jakie są szanse i zagrożenia dla eduka- } \\
\text { cji na poziomie akademickim wynikają- } \\
\text { ce z funkcjonowania nowych technologii } \\
\text { medialnych? }\end{array}$ & $\begin{array}{l}\text { 1. Jakie szanse przynosi obecność nowych mediów i tech- } \\
\text { nologii w procesie nauczania na poziomie akademickim? } \\
\text { 2. Jakie zagrożenia wywołuje obecność nowych mediów } \\
\text { i technologii w szkole wyższej? }\end{array}$ \\
\hline $\begin{array}{l}\text { 2. Jaka jest postawa studentów wobec } \\
\text { obecności nowych technologii medial- } \\
\text { nych i preferencji dotyczących nowocze- } \\
\text { snych form edukacji na uczelni? }\end{array}$ & $\begin{array}{l}\text { 3. Jakie ma Pan/i podejście do używania przez studentów } \\
\text { telefonów, laptopów i innych technologii w czasie trwania } \\
\text { zajęć akademickich? } \\
\text { 4. Jakie ma Pan/i podejście do używania przez wykładow- } \\
\text { ców telefonów, laptopów i innych technologii w czasie } \\
\text { trwania zajęć akademickich? } \\
\text { 5. Co sądzi Pan/i o realizacji przedmiotów w formie on- } \\
\text {-line (kursy, e-learning, odrabianie zajęć za pośrednic- } \\
\text { twem platform e-learningowych)? } \\
\text { 6. Jak wyglądałaby idealna forma przedmiotu realizowa- } \\
\text { nego na Pana/i kierunku studiów (stacjonarny, e-learning, } \\
\text { blended learning)? }\end{array}$ \\
\hline $\begin{array}{l}\text { 3. Jaka jest Pana/i ocena dotychczasowej } \\
\text { formy użycia i poziomu otwartości Uczel- } \\
\text { ni na nowe formy edukacyjne? }\end{array}$ & $\begin{array}{l}\text { 7. Jakich mediów, w jakim celu i jak często używa Pan/i na } \\
\text { zajęciach lub przygotowując się do zajęć? } \\
\text { 8. Z jakimi nowymi formami i narzędziami technologii } \\
\text { medialnych stosowanymi w edukacji najczęściej spoty- } \\
\text { kał/a się Pan/i na studiach? } \\
\text { 9. Jak ocenia Pan/i efektywność używania nowych me- } \\
\text { diów na Wydziale Politologii i Dziennikarstwa UMCS } \\
\text { przez pracowników naukowych? }\end{array}$ \\
\hline $\begin{array}{l}\text { 4. Jakie są prognozy studentów dotyczące } \\
\text { kierunku zmian w edukacji wyższej zwią- } \\
\text { zanych z postępującą mediatyzacją? }\end{array}$ & $\begin{array}{l}\text { 10. Biorąc pod uwagę, że mediatyzacja to przede wszyst- } \\
\text { kim szerokie i głębokie przemiany społeczne i kulturo- } \\
\text { we następujące wraz ze wzrostem obecności mediów } \\
\text { w życiu ludzi, polegające na przekształcaniu i podpo- } \\
\text { rządkowywaniu wielu aktywności człowieka zastoso- } \\
\text { waniu logiki mediów, jakie skutki mediatyzacji eduka- } \\
\text { cji zauważa Pan/i jako student/ka Wydziału Politologii } \\
\text { i Dziennikarstwa UMCS? } \\
\text { 11. Jak będzie wyglądała uczelnia przyszłości? }\end{array}$ \\
\hline $\begin{array}{l}\text { 5. Jakie zmiany w zakresie wykorzystania } \\
\text { technologii medialnych w edukacji wy- } \\
\text { wołało zawieszenie zajęć z powodu epide- } \\
\text { mii COVID-19 w dniu } 11 \text { marca } 2020 \mathrm{r} \text { ? }\end{array}$ & $\begin{array}{l}\text { 12. Czy coś w zakresie wykorzystania technologii medial- } \\
\text { nych w edukacji zmieniło zawieszenie zajęć na UMCS } \\
\text { z powodu epidemii koronawirusa? Jeżeli tak, to w jaki } \\
\text { sposób? }\end{array}$ \\
\hline
\end{tabular}

Źródło: opracowanie własne.

Perspektywa studentów została uzupełniona opiniami wykładowców, którzy realizują programy nauczania w oparciu o nowe technologie medialne. Są oni drugą grupą podmiotów, na których proces mediatyzacji edukacji ma bezpośredni wpływ. To oni muszą zmagać się z transformacjami kulturowymi i społecznymi, w ogromnym zakresie mającymi wpływ na efektywność ich pracy. Są to zarazem osoby, na które nałożony jest obowiązek dostosowywania swojej oferty do zmieniających się 
czynników zewnętrznych. Dobór próby celowej został przygotowany w oparciu o następujące kategorie: płeć, stopień i tytuł naukowy (doktorant/magister, doktor, doktor habilitowany, profesor), przynależność do Katedry Wydziału związanej z naukami o mediach (Katedra Dziennikarstwa, Katedra Informatologii, Bibliologii i Edukacji Medialnej, Katedra Komunikacji Medialnej, Katedra Teorii Mediów, Katedra Administracji Publicznej, Katedra Myśli Politycznej, Katedra Stosunków Międzynarodowych). Kwestionariusze obejmujące 12 pytań zostały wysłane do 27 pracowników naukowych; 14 respondentów odesłało swoje odpowiedzi. Pytania badawcze zamieszczono w tabeli 2.

Tabela 2. Badanie pracowników naukowych Wydziału Politologii i Dziennikarstwa UMCS

\begin{tabular}{|c|c|}
\hline Pytania badawcze & Kwestionariusz dla pracowników naukowych Wydziału \\
\hline $\begin{array}{l}\text { 1. Jakie są szanse i zagrożenia dla } \\
\text { edukacji na poziomie akademickim } \\
\text { wynikające z funkcjonowania nowych } \\
\text { technologii medialnych? }\end{array}$ & $\begin{array}{l}\text { 1. Jakie szanse przynosi obecność nowych mediów i tech- } \\
\text { nologii w procesie nauczania na poziomie akademickim? } \\
\text { 2. Jakie zagrożenia wywołuje obecność nowych mediów } \\
\text { i technologii w procesie nauczania w szkole wyższej? }\end{array}$ \\
\hline $\begin{array}{l}\text { 2. Jaka jest postawa pracowników } \\
\text { naukowych wobec obecności nowych } \\
\text { technologii medialnych oraz prefe- } \\
\text { rencje dotyczące nowoczesnych form } \\
\text { edukacji na uczelni? }\end{array}$ & $\begin{array}{l}\text { 3. Jakie ma Pan/i podejście do studentów używających } \\
\text { telefonów, laptopów i innych technologii w czasie trwania } \\
\text { zajęć akademickich? } \\
\text { 4. Jaki ma Pan/i stosunek do nowoczesnych form naucza- } \\
\text { nia związanych z mediatyzacją edukacji (np. wideoblogi, } \\
\text { filmy, kursy i lekcje online, webinarium itd.)? } \\
\text { 5. Jakich nowych form technologicznych i multimedial- } \\
\text { nych narzędzi edukacyjnych używa Pan/i w dydaktyce? } \\
\text { 6. Czy i w jaki sposób możliwość wykorzystania nowych } \\
\text { mediów ma znaczenie dla planowania metod i narzędzi } \\
\text { nauczania? }\end{array}$ \\
\hline $\begin{array}{l}\text { 3. W jaki sposób pracownicy nauko- } \\
\text { wi postrzegają zmiany w postawie } \\
\text { współczesnego studenta i nauczyciela } \\
\text { spowodowane przez nowe media? }\end{array}$ & $\begin{array}{l}\text { 7. Jakie zmiany w postawie współczesnego studenta wo- } \\
\text { bec edukacji wywołuje obecność nowych mediów? } \\
\text { 8. Jaką postawą i umiejętnościami w kontekście wykorzy- } \\
\text { stania nowych technologii powinien charakteryzować się } \\
\text { współczesny nauczyciel akademicki? } \\
\text { 9. A jak to wygląda w praktyce? }\end{array}$ \\
\hline $\begin{array}{l}\text { 4. Jakie są prognozy naukowców } \\
\text { dotyczące kierunku zmian w edukacji } \\
\text { wyższej związanych z postępującą } \\
\text { mediatyzacją? }\end{array}$ & $\begin{array}{l}\text { 10. Biorąc pod uwagę, że mediatyzacja to wzajemna za- } \\
\text { leżność zmian zachodzących w komunikacji i technologii } \\
\text { medialnej oraz w kulturze i społeczeństwie, jak postrzega } \\
\text { Pan/i rozwój procesu mediatyzacji w edukacji? } \\
\text { 11. Jak będzie wyglądała uczelnia przyszłości? }\end{array}$ \\
\hline $\begin{array}{l}\text { 5. Jakie zmiany w zakresie wykorzysta- } \\
\text { nia technologii medialnych w edukacji } \\
\text { wywołało zawieszenie zajęć z powodu } \\
\text { epidemii COVID-19 w dniu } 11 \text { marca } \\
2020 \mathrm{r} \text { ? }\end{array}$ & $\begin{array}{l}\text { 12. Jakie zmiany dotyczące wykorzystania technologii } \\
\text { medialnych w edukacji zaobserwował/a Pan/i w związ- } \\
\text { ku z zawieszeniem zajęć na UMCS z powodu epidemii } \\
\text { koronawirusa? }\end{array}$ \\
\hline
\end{tabular}

Źródło: opracowanie własne. 
Zestawy pytań zamieszczone w kwestionariuszu pozwoliły na poznanie ogólnej oceny zjawiska mediatyzacji edukacji na poziomie akademickim z perspektywy studentów i pracowników naukowych, czyli podmiotów, których skutki postępującej mediatyzacji dotykają bezpośrednio. Badania miały charakter eksploracyjny, ze względu zarówno na szybkość aktualnie postępujących zmian w edukacji, szczególnie w okresie izolacji społecznej, jak i na fakt, że sposoby postrzegania tych zmian na razie zostały zbadane w niewielkim stopniu lub wcale. Równie ważnym celem badań było wywołanie dyskusji na temat przemian w systemie edukacji napędzanych przez media oraz poziomu otwartości na te przemiany wśród studentów i wykładowców, a także ustalenie kierunku tych zmian.

\section{Wyniki badań własnych}

Zgromadzone wyniki badań studentów pozwoliły na sformułowanie kilku istotnych wniosków. Analizując odpowiedzi na pierwsze pytanie badawcze (pytania 1 i 2 z kwestionariusza dla studentów), można zauważyć, że studenci potrafią wskazać zarówno zalety, jak i wady wzrastającego udziału nowych mediów w przestrzeni akademickiej. Do najczęściej wymienianych przez respondentów zalet wykorzystywania nowych technologii medialnych należy zaliczyć: umożliwienie i rozwój form studiowania na odległość; zwiększenie szybkości zdobywania informacji i ułatwienie dostępu do ich zasobów; wzmocnienie zaangażowania i urozmaicenie zajęć. Korzyści z nowych mediów w przestrzeni akademickiej studenci docenili szczególnie w trakcie pandemii: Wydaje się, że odpowiedź na to pytanie nasuwa się teraz, $w$ dobie epidemii, kiedy właściwie dzięki nowym mediom możemy w miarę normalnie funkcjonować i uczestniczyć w wykładach, konwersatoriach, zaznaczając swoją obecność i uczestnictwo.

Studenci sprawnie rozpoznają szanse i zagrożenia mediatyzacji edukacji i są świadomi wpływu logiki mediów na funkcjonowanie systemu edukacji wyższej. Znacznie chętniej wypowiadają się na temat zagrożeń niż szans, co może świadczyć o niechęci wobec nowych form edukacyjnych oraz o obawie w stosunku do nich: Brak samodzielności powoduje, że w dobie nowych mediów i Internetu studenci stają się zbyt leniwi. Wyszukiwanie materiałów do pracy jest zdecydowanie łatwiejsze i szybsze, co może prowadzić do braku zaangażowania.

Co istotne, studenci nie mają pozytywnego nastawienia do obecności nowych technologii (drugie pytanie badawcze) stosowanych w celach prywatnych podczas zajęć akademickich zarówno przez studentów, jak i przez wykładowców (pytania 3 i 4 z kwestionariusza dla studentów). Przyznają jednak, że najważniejszą kwestią jest tu motywacja, którą się kierują, sięgając po smartfon lub laptop. Jednocześnie nie widzą problemu, jeśli chodzi o używanie telefonów sporadycznie, w wyjątkowych przypadkach: Uważam, że jest to poniżej wszelkiej krytyki, jest to nie na miejscu i moim zdaniem jest to brak szacunku do wykładowcy, jak również do jego pracy. Jeśli chodzi 
o laptopa, sytuacja jest podobna. Jeżeli służy on do zapisywania notatek z zajęć, to w porzadku. Korzystanie w celach rozrywkowych odpada.

Ponadto studenci mają tradycjonalistyczne podejście do edukacji i zdecydowanie opowiadają się za stacjonarną formą zajęć (pytania 5 i 6 z kwestionariusza dla studentów). Jedyną akceptowalną dla nich opcją unowocześnienia studiów byłby blended learning, łączy bowiem w sobie zalety tradycyjnych spotkań z innowacyjnymi, aktywizującymi formami medialnymi: Jako tradycjonalista uważam, że nie można zastąpić spotkan "twarza w twarz" z prowadzącymi zajęcia. Myśle, że e-learning to forma dodatku, który może być używany w wyjątkowych sytuacjach.

Respondenci pozytywnie ocenili efektywność używania nowych mediów przez kadrę naukową Wydziału (trzecie pytanie badawcze); szczególnie wyróżnili młodszych pracowników, którzy chętniej sięgają po nowe media: Widać znacząca poprawę w sprawie efektywności używania nowych mediów przez pracowników naukowych i myślę, że z czasem efektywność wzrośnie jeszcze bardziej.

Zdaniem ankietowanych wszelkie próby zachęcenia studentów do aktywnego udziału w zajęciach poprzez stosowanie nowych technologii medialnych są słuszne. Respondenci najchętniej i najczęściej korzystają z przenośnych urządzeń medialnych (smartfon, laptop), które służą im na zajęciach jako narzędzie do wyszukiwania informacji w Internecie lub do notowania (pytanie 7 z kwestionariusza dla studentów). Najczęściej używane są przeglądarki internetowe, poczta elektroniczna, media społecznościowe i serwis YouTube. Wskazując na nowe narzędzia, z jakimi spotkali się na studiach (pytanie 8 z kwestionariusza dla studentów), respondenci wymienili: Wirtualny Kampus, MS Teams, prezentacje Power Point, Skype, Kahoot, tablice interaktywne, YouTube, media społecznościowe (Instagram, Facebook, Twitter), Zoom, Ted-Ed, Netflix, Discord. Oceniając efektywność ich użycia przez pracowników naukowych, studenci biorący udział w badaniu stwierdzili, że kadra naukowa dobrze radzi sobie z nowymi technologiami (pytanie 9 z kwestionariusza dla studentów). Należy jednak zaznaczyć, że nowe media są wciąż negatywnie postrzegane przez studentów, którzy niechętnie biorą udział w takich formach zajęć: Uważam, że technologiczna ułomność zajęć na politologii ma swoje duże zakorzenienie $w$ obojętności studentów co do przedmiotu i chęci odbębnienia go, byleby zaliczyć semestr. Myślę, że jest to spory demotywator dla wykładowców, którzy faktycznie chcieliby przekazać dalej wiedzę ze swoich specjalizacji.

W wynikach badania opinii studentów na temat kierunku zmian na uczelni wraz z postępującą mediatyzacją edukacji (czwarte pytanie badawcze) można dostrzec przekonanie o pogłębiającej się reorganizacji trybu studiów i sukcesywnym przenoszeniu go do świata wirtualnego (pytanie $10 \mathrm{z}$ kwestionariusza dla studentów). Respondenci uznali jednocześnie, że zmiany te będą powolne i przybiorą formę ewolucji uczelni ku e-uczelni: Myślę, że część realizowanych zadań przeniesie się do rzeczywistości wirtualnej i będzie w większym stopniu na niej polegać. Wydaje mi się, że to dobry czas na zmiany, które niejako narzucają nam konieczność wykorzystywania nowych technologii 
w procesie nauczania. Mam wrażenie, że mimo wszystko próbujemy jeszcze walczyć $z$ taka forma nauki, co jest oczywiście błędem.

W najbliższym czasie studenci spodziewają się zwiększonego udziału narzędzi e-learningowych i blended learningowych oraz zwiększenia zakresu e-administracji uczelni (pytanie 11 z kwestionariusza dla studentów).

Okres pandemii COVID-19 stanowi wyzwanie dla studentów i pracowników naukowych. Szybko okazało się, że znajomość nowych mediów i platform przeznaczonych do zdalnego nauczania jest niezbędna we współczesnej rzeczywistości akademickiej (piąte pytanie badawcze). Pozwolił on również dostrzec potencjał i przydatność technologii medialnych oraz pomógł obu stronom edukacji oswoić się z nową formą zmediatyzowanej uczelni (pytanie $12 \mathrm{z}$ kwestionariusza dla studentów): Myślę, że i studenci, $i$ wykładowcy zauważli potencjał technologii $w$ wykorzystaniu do celów akademickich. Spodziewam się również, że po powrocie na zajęcia stacjonarne wykładowcy będa wykorzystywać częściej dostępne technologie.

Nie tylko współcześni studenci, ale też pracownicy naukowi aktywnie działający w przestrzeni akademickiej w dobie nowych mediów są obserwatorami zmian zachodzących pod wpływem mediatyzacji edukacji. Respondenci drugiej części badań chętnie wskazywali zarówno zalety, jak i wady wzrastającego udziału nowych mediów w przestrzeni akademickiej (pierwsze pytanie badawcze). Wśród zalet najczęściej wymieniano: ułatwienie procesu komunikacji ze studentem; wygodę i usprawnienie kontaktu; poszerzenie możliwości przesyłania informacji, materiałów i zasobów wzbogacających przekaz naukowy (materiały filmowe, prezentacje); nieograniczone zasoby danych, literatury przedmiotu, multimediów; uatrakcyjnienie procesu uczenia; wdrażanie nowoczesnych technik nauczania do codziennej praktyki akademickiej (pytanie $1 \mathrm{z}$ kwestionariusza dla pracowników naukowych). Znacznie częściej wypowiadano się jednak na temat zagrożeń i negatywnego wpływu mediów. W odpowiedzi na ogólne pytanie dotyczące zagrożeń wnoszonych do edukacji przez media respondenci skupiali się zazwyczaj na problemach leżących po stronie studentów i złym wpływie na nich (pytanie 2 z kwestionariusza dla pracowników naukowych): Pojawia się też przekonanie, że pamięć to coś zbędnego, że zawsze można wyciagną́ smartfon z kieszeni i znaleźć odpowiedź na każde pytanie; Kwestie prawne wskazuje $z$ kolei, bo wydaje mi się, że większość użytkowników nowych mediów i technologii ma problem z jednoznacznym rozstrzygnięciem, co moga, a czego nie moga robić podczas ich wykorzystywania.

Pracownicy naukowi mają pozytywny stosunek do obecności nowych technologii podczas zajęć akademickich (drugie pytanie badawcze), ale pod warunkiem, że są one używane w celach naukowych: Jeśli studenci używaja tych urządzeń do notowania, nagrywania lub poszukiwania informacji bądź tworzenia komunikatów związanych $z$ zajęciami, cenię to.

Omawiana grupa respondentów ma świadomość, że niestety zazwyczaj nowe technologie służą studentom do celów prywatnych. Nie opracowano jednak jak do- 
tąd metod weryfikacji i minimalizowania niepotrzebnego używania smartfonów czy laptopów podczas zajęć (pytanie 3 z kwestionariusza dla pracowników naukowych): Problem $w$ tym, że bardzo często $w$ czasie wykładu wykorzystuja komputer do odpisywania znajomym, ogladania filmów, grania, a to oznacza zerowa efektywność obecności studenta na wykładzie. Student skupia się wtedy na innych - z jego perspektywy ciekawszych - sprawach niż wykład; Szczerze? Jeszcze kilka lat temu irytowało mnie to, ale idac $z$ duchem czasu, uznaje, że jest to walka $z$ wiatrakami. Pozostaje jedynie wykorzystać to zaangażowanie $w$ procesie dydaktycznym, np. poprzez zadanie wyszukania konkretnych treści w tych mediach, odpowiadających tematowi zajęć.

Najlepszą formą na wykorzystanie wysokiego poziomu zaangażowania studentów w świat cyfrowych technologii jest w opinii respondentów efektywne i mądre użycie technologii informacyjno-komunikacyjnych (TIK) w edukacji (pytanie 4 z kwestionariusza dla pracowników naukowych): Nowe media umożliwiają przełożenie abstrakcji teorii naukowych na praktykę działań. Pozwalają bowiem na prezentacje przykładów, pracę „na żywym organizmie”, co jest szczególnie ważne dla uczestników studiów z zakresu nauk społecznych. Sa obszarem badań.

Respondenci wykazali się jednocześnie zdroworozsądkowym podejściem, podkreślili bowiem fakt, że nowe media powinny być traktowane w tym aspekcie z ostrożnością i ograniczonym zaufaniem. Sami chętnie stosują nowe technologie w pracy, a wraz z rozwojem TIK częściej i odważniej biorą udział w kursach przygotowawczych oraz realizują część swoich zajęć z wykorzystaniem tych metod. Pracownicy naukowi biorący udział $\mathrm{w}$ badaniu, zapytani o to, jakich nowych narzędzi dydaktycznych używają (pytanie 5 z kwestionariusza dla pracowników naukowych), najczęściej wymieniali: prezentację multimedialną, filmy, Prezi, Wirtualny Kampus, MS Teams, StartLeaf, Moodle, Kahoot, YouTube, Netflix, Player, NC Go, webinaria, aplikacje mobilne i wyszukiwarki, blogi itd. Warto zaznaczyć, że traktują je nadal jako formę towarzyszącą tradycyjnej edukacji, której technologie nie powinny zastąpić w pełnym wymiarze.

Wykładowcy mają jednak tradycjonalistyczne podejście do edukacji i zdecydowanie opowiadają się za stacjonarną formą zajęć. Nowe narzędzia medialne są traktowane przez nich jako metoda aktywizacji czy grywalizacji lub stosowane są w celu wzbogacenia przekazu (pytanie $6 \mathrm{z}$ kwestionariusza dla pracowników naukowych), przy czym sytuacja pandemiczna pomogła im w przełamaniu swoich dotychczasowych barier, w efekcie czego chętnie sięgają po nie i deklarują, że będą to robić także w przyszłości: Bywaja przydatne, szczególnie w sytuacjach skrajnych (pandemia), ale bym ich nie fetyszyzował, z reguły lepszy jest kontakt bezpośredni i zajęcia „w klasie”. Innymi słowy, sa znakomita alternatywa, gdy nie ma możliwości pracy offline.

Respondenci z niepokojem obserwują zmiany zachodzące w postawie współczesnego studenta (pytanie $7 \mathrm{z}$ kwestionariusza dla pracowników naukowych): Student uważa, że wie więcej, ponieważ ma nieograniczony dostęp do informacji. W pojęciu młodych osób wartość stanowi wiedza, ponieważ podnosi ich samozadowolenie z siebie. To jest OK, oby tylko nie wyłaczyło logicznego myślenia, kreatywności i humanitaryzmu. 
Jednocześnie pozytywnie ocenili efektywność używania nowych mediów przez siebie i kadrę pracowników naukowych Wydziału. Wierzą, że wszelkie praktyki związane z edukacją online są wartościowe, a współczesny nauczyciel powinien się w tej dziedzinie stale rozwijać i dokształcać (pytanie 8 z kwestionariusza dla pracowników naukowych): Nauczyciel akademicki nie powinien kontestować nowych technologii czy udawać, że nie istnieją. Nie może też obrażać się na „inność" młodego pokolenia, lecz dostosowywać do niego metody dydaktyczne, $w$ tym właczać nowe technologie do ćwiczeń czy wykładów.

Dodać w tym miejscu trzeba, że zdaniem badanych pracowników naukowych należy z dystansem podchodzić do zastępowania całej swojej dotychczasowej działalności formami cyfrowymi, być wobec nich selektywnym i krytycznym oraz używać ich w świadomy, kompetentny sposób (pytanie 9 z kwestionariusza dla pracowników naukowych): Obserwuję postawy wręcz fascynacji możliwościami nowych technologii lub przeciwnie, ucieczki od technologii. Jak zawsze sprawdza się zasada złotego środka: racjonalność i ocena przydatności technologii do konkretnych zajęć, a nawet ich części.

Zdaniem pracowników naukowych wraz z postępującą mediatyzacją edukacji uczelnia będzie starała się odpowiedzieć na potrzeby studentów i stopniowo przenosić się do przestrzeni wirtualnej (czwarte pytanie badawcze). Respondenci stwierdzili, że możliwe jest, iż w przyszłości będą działały jednocześnie e-uczelnie (wersja ekonomiczna) i uczelnie stacjonarne (wersja droższa). W najbliższym czasie spodziewają się więc zwiększonego udziału narzędzi technologii medialnych, szkoleń dla pracowników przygotowujących do pracy zdalnej oraz badań skuteczności i efektywności nauczania przez Internet (pytanie $10 \mathrm{z}$ kwestionariusza dla pracowników naukowych): Obecny kryzys bardzo mocno zmieni sytuacje - bo okazuje się, że można część procesu dydaktycznego przenieść do środowisk online. Ten proces dydaktyczny jest jakościowo „gorszy”, ale jest nieporównywalnie tańszy i wszyscy zainteresowani (władze uczelni, ministerialni politycy) to wiedza. Mysle więc, że czekaja nas zmiany; Nie ma ucieczki od nowych technologii, także w dydaktyce akademickiej. Rozwój tego procesu jest dużym wyzwaniem. Brakuje przygotowania i narzędzi z poziomu centralnego. Większość wykładowców została rzucona na glęboka wodę i musza dostosowywać się do zastanej sytuacji. Rodzi to spory chaos. Niektórzy studenci też z dystansem podchodza do nowych rozwiazańn.

Jednocześnie respondenci wierzą $\mathrm{w}$ to, że relacja uczeń - nauczyciel nie ulegnie zmianom i tradycyjny kształt relacji akademickich zostanie zachowany (pytanie 11 z kwestionariusza dla pracowników naukowych): Nie umiem prorokować. Niech po prostu będzie, niech nie zniknie jako miejsce bardzo szczególnego rozwoju i spotkania, wzajemnego kształtowania się wykładowców i studentów. Niech naukowców nie zastapia komputery, niech kultura rozmowy, dyskusji, umiejętność stuchania się wzajemnie nie zostanie zastapiona przez forum, a egzaminy ustne przez test „abcd”, przynajmniej w naukach humanistycznych i społecznych. Marzę więc o uczelni, która będzie usprawniona tam, gdzie to bardzo przydatne, przez nowe technologie, ale zachowa to, co od wieków stanowiło o jej szczególności - kulturę spotkania. 
Czas pandemii COVID-19 uświadomił respondentom, jak ważna jest świadomość istnienia oraz znajomość nowych mediów i platform do zdalnego nauczania (piąte pytanie badawcze). Wykładowcy, dla których prowadzenie zajęć online było nowością, dostrzegli wiele zalet tej formy nauczania (wygoda, elastyczność czasu pracy, atrakcyjne formy aktywizacji), ale także wad (prowizoryczność, spłaszczenie komunikacji, ograniczona i wydłużona w czasie komunikacja pośrednia ze studentem). Ponadto doszli do wniosku, że znajomość nowych technologii medialnych w edukacji jest niezbędna we współczesnej rzeczywistości akademickiej. Dodatkowo dostrzeżono potencjał i przydatność technologii medialnych, pomogły one bowiem obu stronom edukacji oswoić się z nową formą zmediatyzowanej uczelni (pytanie $12 \mathrm{z}$ kwestionariusza dla pracowników naukowych): Sytuacja i przepisy wymusity prowadzenie zajęć przez konkretne platformy, w tym Wirtualny Kampus, z którego i ja nauczyłam się wreszcie korzystać, na razie w podstawowym zakresie. Wiem, że koleżanki i koledzy korzystaja z Microsoft Teams, niektórzy nawet z Facebooka. Dla osób o mojej mentalności Wirtualny Kampus jest w sam raz. Już wiem, że będę z niego korzystać także po zakończeniu izolacji, postuży mi na pewno do sporadycznego prowadzenia zajęć zdalnych, gdy z jakichś ważnych powodów nie będę mogła przeprowadzić zajęć na uczelni, albo do stworzenia bazy lektur w PDF czy linków $z$ materiałami.

Ta część respondentów, którzy mieli do czynienia z nowoczesnymi narzędziami w swojej praktyce zawodowej, nie zauważyła znaczących zmian w stosowaniu nowych narzędzi edukacyjnych, a jedynie znacząco zwiększyła ich wykorzystanie w czasie pandemii: W moim przypadku żadnych. Pracuje prawie tak samo, jak przed pandemiq (bez przychodzenia na zajęcia stacjonarne).

Wprawdzie nie można założyć, że obecna sytuacja na trwałe zmieni kształt dotychczasowych praktyk akademickich, lecz z pewnością zmiany zostały przyspieszone, choć prawdopodobnie na nowo zwolnią, gdy uczelnie będą mogły wrócić do normalnego trybu pracy. Trwałe przekształcenia w szkolnictwie wyższym powodowane przez mediatyzację powinny być kontrolowane i sprawdzane na każdym etapie, dlatego naukowcy uważają, że proces będzie przebiegał wolniej i swobodniej niż ten, który ma miejsce obecnie: Tak jak już wskazywałem, wielu pracowników dydaktycznych musiało w trybie natychmiastowym opanować techniki i sposoby zdalnego nauczania. Chociaż wiele rozwiązań istniało, a uczelnia dawała możliwości ich rozpoznania chociażby poprzez kursy i szkolenia, to nie wzbudzało zainteresowania. Obawiam się, że jak pandemia się skończy, wiele aspektów powróci do swojego dawnego kształtu.

\section{Wnioski}

Mediatyzacja edukacji to niewątpliwie jeden z najbardziej widocznych procesów zachodzących obecnie w sferze społeczno-kulturowej. Przedstawione w niniejszym opracowaniu zagadnienia teoretyczne, przybliżające genezę i podstawy badawcze 
mediatyzacji oraz jej namacalne skutki, objawiające się m.in. przekształceniem życia codziennego, zawodowego i społecznego każdego człowieka, który jest otoczony mediami, a także zmiany w postrzeganiu rzeczywistości przez nowy pryzmat i logikę mediów oraz konieczność posiadania kompetencji medialnych wyraźnie to pokazują. Te i wiele innych widocznych zmian wskazuje na to, jak istotna wydaje się być dyskusja na temat niezaprzeczalnych szans i zagrożeń, jakie niesie za sobą mediatyzacja w przestrzeni akademickiej. Opisane tu badania mogą stanowić bazę poglądową na temat postaw dwóch najistotniejszych grup, których proces ten dotyczy w szczególności: studentów i pracowników naukowych. Fakt, że badania zostały zrealizowane w wyjątkowym czasie, sprawia, że zyskały wartość dodatkową, jaką jest aktualność i dostrzegalność opisywanych przemian przez grupy osób badanych.

Zaprezentowane wyniki badań przeprowadzonych wśród pracowników naukowych i studentów Wydziału Politologii i Dziennikarstwa UMCS jasno wskazują zarówno punkty zbieżne, jak i różnice. Dzięki nim widać także, jak bardzo obie grupy cenią dotychczasowy tryb pracy na uczelni i jak duże obawy wiążą z wszelkimi zmianami.

Niewątpliwie proces mediatyzacji będzie rozciągnięty w czasie. Uczelnia w procesie ewolucji przekształci swoją ofertę tak, by dopasować się do potrzeb zmediatyzowanego społeczeństwa. Przebiegnie to jednak zdecydowanie wolniej niż mogłyby na to wskazywać radykalne przemiany związane z pandemią COVID-19 i zamknięciem uczelni. Sytuacja ta wyraźnie pokazała, że żadna z grup nie jest jeszcze wystarczająco przygotowana do przejścia $\mathrm{w}$ całości do trybu zdalnego, a stosowane rozwiązania technologiczne wymagają dopracowania, by mogły w pełny i wartościowy sposób konkurować z tradycyjnym trybem studiów. Po pokonaniu przeszkód technicznych i opracowaniu optymalnego sposobu korzystania z nowych mediów w edukacji ważne będzie również pokonanie oporu i niechęci do zmian zarówno studentów, jak i wykładowców.

Kierunek przemian edukacji na poziomie akademickim jest z pewnością jasny. Wszystko wskazuje na to, że udział nowych technologii medialnych będzie stale i sukcesywnie wzrastał, a część programów studiów zostanie w całości przeniesiona na platformy e-learningowe. Ważne jest to, by proces digitalizacji uczelni przebiegał zgodnie z naturalnym rytmem, nie był przyspieszany ani spowalniany oraz by oferta edukacyjna była na bieżąco konfrontowana z ciągłymi przekształceniami społeczeństwa zmediatyzowanego.

\section{Bibliografia}

Adolf, M. (2013). Clarifying mediatization: Sorting through a current debate. Empedocles: European Journal for the Philosophy of Communication, 3(2), 153-175. doi:10.1386/ejpc.3.2.153_1 Couldry, N. (2008). Mediatization or mediation? Alternative understandings of the emergent space of digital storytelling. New Media \& Society, 10(3), 373-391. doi:10.1177/1461444808089414 
Czopek, J. (2016). Bezpieczeństwo i ochrona prywatności młodzieży w Internecie w kontekście edukacji medialnej. Zeszyty Naukowe WSH Pedagogika,12, 67-73.

Dogan, V. (2019). Why Do People Experience the Fear of Missing Out (FoMO)? Exposing the Link Between the Self and the FoMO Through Self-Construal. Journal of Cross-Cultural Psychology, 50(4), 1-15. doi:10.1177/0022022119839145

Drzewiecki, P. (2010). Media aktywni. Dlaczego i jak uczyć edukacji medialnej? Warszawa: Instytut Edukacji Medialnej i Dziennikarstwa UKSW.

Flak, Ł., Kropisz, J., \& Flak, R. (2019). Marketing w dobie ery cyfrowej: profilowanie konsumenta w sieci. W: A. Krzysztofek, \& A. Borcuch (red.), Nowe konteksty w nauce XXI wieku (s. 41-48). Kielce: Laboratorium Wiedzy Artur Borcuch.

Frania, M. (2017). Nowe media, technologie i trendy w edukacji. Kraków: Oficyna Wydawnicza Impuls.

Hepp, A. (2012). Cultures of Mediatization. Cambridge: Polity Press.

Hepp, A. (2020). Deep Mediatization. London-New York: Routledge.

Hepp, A., \& Hasebrink, U. (2018). Researching Transforming Communications in Times of Deep Mediatization: A Figurational Approach. W: A. Hepp, A. Breiter, \& U. Hasebrink (Eds.), Communicative Figurations. Transforming Communications - Studies in Cross-Media Research (s. 15-48). Basingstoke: Palgrave Macmillan.

Hjarvard, S. (2008). The Mediatization of Society: A Theory of the Media as Agents of Social and Cultural Change. Nordicom Review, 29(2), 105-134. doi:10.1515/nor-2017-0181

Livingstone, S. (2014). The Mediatization of Childhood and Education: Reflections on the Class. W: L. Kramp, N. Carpentier, A. Hepp, I. Tomanić Trivundža, H. Nieminen, R. Kunelius, T. Olsson, E. Sundin, \& R. Kilborn (Eds.), Media Practice and Everyday Agency in Europe (s. 55-68). Bremen: edition lumière.

Lundby, K. (2014). Mediatization of Communication. W: K. Lundby (Ed.), Mediatization of Communication: Handbooks of Communication Science (s. 3-35). Berlin: De Gruyter Mouton.

Nowak-Teter, E. (2019). Mediatization: Conceptual developments and research domains. Sociology Compass, 13(4), 1-10. doi:10.1111/soc4.12672

Spitzer, M. (2016). Cyberchoroby. Jak cyfrowe życie rujnuje nasze życie. Słupsk: Dobra Literatura.

Valtonen, T., Tedre, M., Mäkitalo, K., \& Vartiainen, H. (2019). Media Literacy Education in the Age of Machine Learning. Journal of Media Literacy Education, 11(2), 20-36. doi:10.23860/ JMLE-2019-11-2-2 